\title{
Interannual Variation of Tropical Cyclone Activity over the Central North Pacific
}

\author{
James D. CLARK \\ Marine Prediction Center, National Center for Environmental Prediction (NCEP) / National Weather Service, \\ Camp Springs, MD, USA \\ and \\ Pao-Shin CHU \\ Department of Meteorology, School of Ocean and Earth Science and Technology, University of Hawaii, \\ Honolulu, HI, USA
}

(Manuscript received 23 February 2000, in revised form 4 February 2002)

\begin{abstract}
The annual mean number of tropical cyclones in the Central North Pacific (CNP) is approximately three. Although this number is low in comparison to other basins, the interannual variability of tropical cyclones, which includes tropical storms and hurricanes, is high. For the period 1966-1997, the annual number ranges from 0 to 10 tropical cyclones.

There is a large and positive correlation between CNP tropical cyclone counts and El Niño 3.4 region SST anomalies with a 95\% significance level. In the El Niño Hurricane Season (ENHS), a greater number of cyclones formed in the CNP and more cyclones propagated into this area from the east. The monsoon trough, low level relative vorticity, and tropospheric vertical wind shear in the CNP undergo pronounced changes during warm and cold phases of ENSO.

For instance, the $1000 \mathrm{hPa}$ relative vorticity values within the CNP in an El Niño autumn composite are double the values in a corresponding La Niña composite. The El Niño autumn composite of tropospheric vertical wind shear shows a two to three times reduction equatorward of $16^{\circ} \mathrm{N}-17^{\circ} \mathrm{N}$ when compared to the La Niña autumn composite. The increased values of the dynamic potential term in Gray's (1977) seasonal genesis parameter correspond well with the increased cyclone frequency in the CNP for an ENHS composite. Furthermore, a majority of initial detection points of named storms is found within a band of relatively large values of dynamic potential. This suggests that this term can be used to diagnose favorable areas for tropical cyclogenesis on a seasonal time scale.
\end{abstract}

\section{Introduction}

The interannual variability of tropical cyclones in the Central North Pacific (CNP hereafter) has not been well documented. Figure 1

Corresponding author: Pao-Shin Chu, Department of Meteorology, University of Hawaii at Manoa, 2525 Correa Road, Honolulu, HI 96822, U.S.A.

E-mail: chu@soest.hawaii.edu

(C) 2002, Meteorological Society of Japan shows the domain of the CNP, which extends from the equator northward and from $140^{\circ} \mathrm{W}$ to the dateline. From 1966 to 1997, there is an annual average of approximately three tropical cyclones (designated TCs hereafter), which include tropical storms and hurricanes. Although the annual mean counts of TCs is low, the CNP is marked by pronounced interannual and decadal variations (Chu and Wang 1997; Chu and Clark 1999; Chu 2002). The CNP has been 


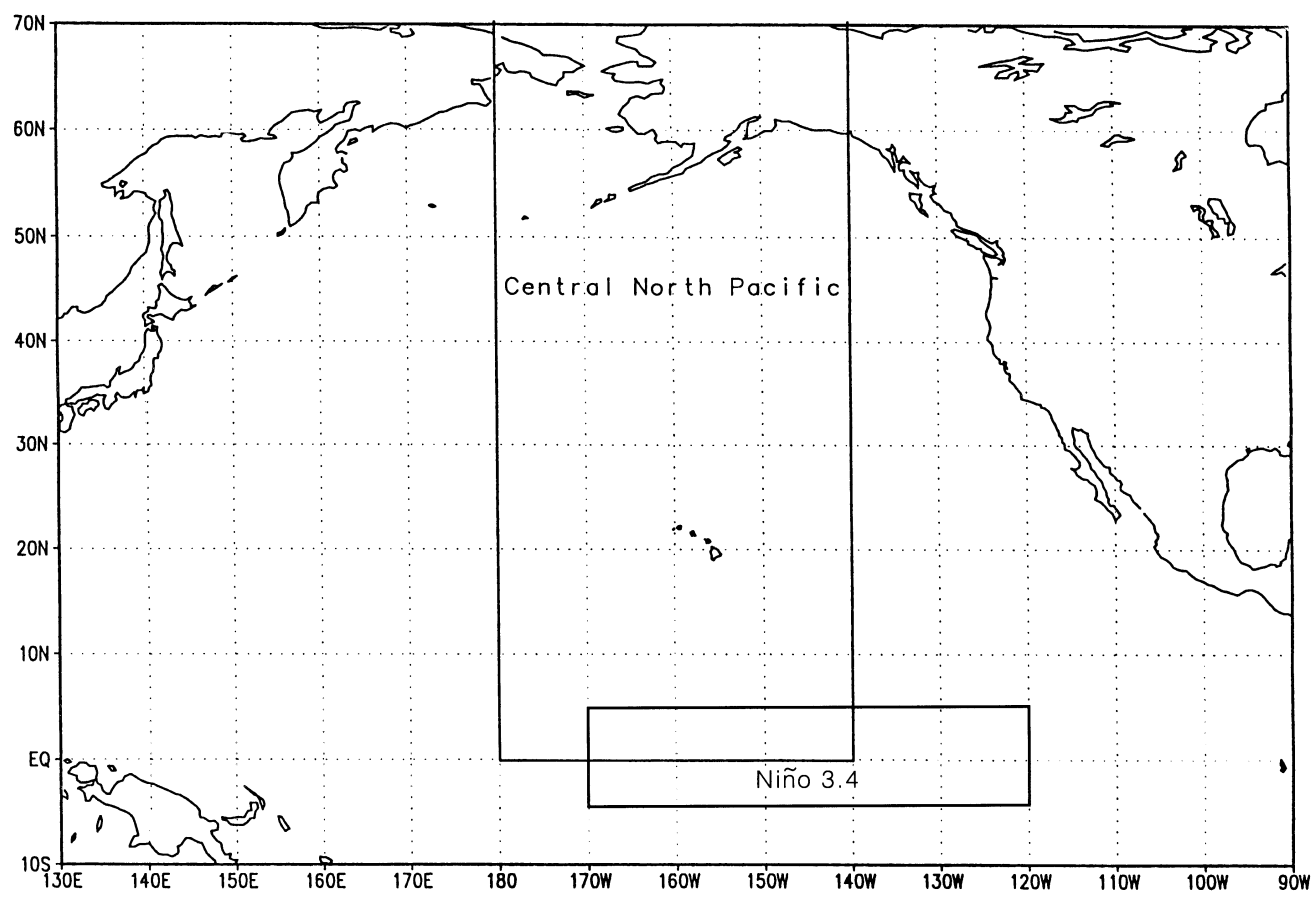

Fig. 1. Orientation map. The Central North Pacific (CNP) and the Niño 3.4 region are delineated by solid lines.

largely ignored as an area for TC activity even though TCs in this region can pose a threat to the Hawaiian Islands. For example, Hurricane Iniki struck the island of Kauai in 1992, and caused an estimated $\$ 2$ to $\$ 3$ billion of damage to the island chain.

Numerous previous studies have been conducted on the interannual variability of TCs in other ocean basins. Most prior work has correlated TC frequency in various basins to regional, local parameters as well as global, remote factors. Gray (1984) related Atlantic seasonal hurricane frequency to El Niño and the quasi-biennial oscillation of stratospheric wind. Gray (1990), Landsea and Gray (1992), and Landsea et al. (1992) investigated the relationship between Western Sahel monsoon rainfall and the occurrence of intense hurricanes in the Atlantic. Shapiro (1987), and Shapiro and Goldenberg (1998), related TC formation in the Atlantic to regional Atlantic tropical circulation features and sea surface temperatures (SST).

Studies by Chan (1985, 2000), Lander (1994), and Chen et al. (1998) attempted to find a rela- tionship between TC activity in the Western North Pacific and the El Niño and La Niña phenomena. They noted that the TC genesis region shifts eastward across $160^{\circ} \mathrm{E}$ in the Western North Pacific in El Niño years while the genesis region is mostly confined to the west of $160^{\circ} \mathrm{E}$ during La Nina. Basher and Zheng (1995) performed a similar study investigating the spatial patterns of TCs in the southwest Pacific in relation to the El NiñoSouthern Oscillation (ENSO) and regional SSTs. In the eastern North Pacific, Irwin and Davis (1999) noted a statistically significant westward shift in the mean location of TCs during El Niño years relative to La Niña years. This result is consistent with Kimberlain (1999), who analyzed tropical cyclone tracks over the eastern and central North Pacific for the five warmest and coldest ENSO events. Although numerous studies have examined the interannual variability of TCs in other basins, little research has been done on the subject in the CNP.

Sadler (1967) established that most TCs in the Western North Pacific form in the monsoon 
trough marked by westerlies on its equatorward side and easterlies on its poleward side. A circulation anomaly common to strong negative phases of the Southern Oscillation Index (SOI) is an eastward extension of the western Pacific monsoon trough to the Central Pacific where it becomes highly persistent and extends eastward with time (e.g., Sadler 1983). When the monsoon trough extends farther eastward, it is hypothesized to play a role in CNP TC genesis (Chu and Wang 1997). Tropospheric vertical wind shear is known as a major inhibiting factor for TCs (Gray 1968, 1977). Gray (1977) found that seasonal TC frequency is directly related to six physical parameters and these parameters can be classified into two groups: dynamic and thermal potential terms.

Our focus lies on the dynamic potential term and how the parameters in this term vary in association with El Niño and La Niña phenomena. The dynamic circulation parameters that were investigated include the eastward extension of the monsoon trough, the low-level relative vorticity, and tropospheric vertical wind shear fields. In addition, the effects of El Niño and La Niña on TC frequency in the CNP were quantified. Once a difference in TC tracks and numbers was established between El Niño and La Niña hurricane seasons, the above dynamic circulation parameters were analyzed. We applied the dynamic potential term from Gray's (1977) seasonal genesis parameter (SGP) to the CNP in an attempt to isolate the dynamic variables responsible for $\mathrm{TC}$ occurrences, and to determine the areas with the most potential for TCs.

\section{Data}

Tropical storm (maximum sustained surface wind speeds between 17.5 and $33 \mathrm{~m} \mathrm{~s}^{-1}$ ), and hurricane (winds at least $33 \mathrm{~m} \mathrm{~s}^{-1}$ ) data, are from the National Centers for Environmental Prediction (NCEP)/Tropical Prediction Center's (TPC) Northeast and CNP best track data set. Mayfield and Rappaport (1992) suggest that reliable tropical cyclone statistics in the CNP began in 1966, when satellite reconnaissance was initiated in the region. Therefore, data from 1966 to 1997 are used. The latitude, longitude, maximum one-minute sustained wind speed, and minimum central surface pressure (since 1988) are recorded in 6-hour intervals for all named storms in the best track data set (Chu and Wang 1998).

Niño 3.4 region SST and SOI data were obtained from the NCEP/Climate Prediction Center. The motivation for choosing the Niño 3.4 region, which covers an area between $5^{\circ} \mathrm{N}-5^{\circ} \mathrm{S}$ and $170^{\circ} \mathrm{W}-120^{\circ} \mathrm{W}$ (Fig. 1), as an index was Barnston et al. (1997). They determined that ENSO is most reliably reflected in the equatorial SST from approximately $120^{\circ} \mathrm{W}$ westward to near the date line. The Niño 3.4 region is close to the Pacific warm pool, and the major center of convection during ENSO (Trenberth 1997). Wind data at the $1000 \mathrm{hPa}, 850 \mathrm{hPa}$, and $200 \mathrm{hPa}$ levels and relative vorticity data at the $1000 \mathrm{hPa}$ level are utilized from the NCEP/National Center for Atmospheric Research reanalysis project (Kalnay et al. 1996).

\section{Background}

\subsection{Basic descriptions of tropical cyclones}

The domain of the CNP coincides with the area of responsibility for the Central Pacific Hurricane Center, an entity of the U.S. National Weather Service Forecast Office in Honolulu, Hawaii. Two types of TCs appear in this region. TC counts include storms which form within the domain of the CNP, as well as storms which form in the Eastern North Pacific, and propagate into the CNP. TC genesis is defined as the point at which a TC first attains a $17.5 \mathrm{~m} \mathrm{~s}^{-1}$ maximum surface wind speed. TC frequency includes the movement of a TC with at least a $17.5 \mathrm{~m} \mathrm{~s}^{-1}$ maximum surface wind speed into the CNP.

Time series of the annual number of TCs in the CNP are displayed in Fig. 2. For the years 1966-1997, the annual number ranges from 0 TCs $(1969,1975,1977,1979)$ to 10 TCs (1982). There is an annual mean of $2.8 \mathrm{TCs}$.

\subsection{Correlation between tropical cyclones and ENSO}

To determine if the CNP TC season is influenced by ENSO, correlation coefficients between various counts of TCs and different time averages of both the Niño 3.4 region SST anomalies, and the SOI were calculated. Summer (June-August), autumn (SeptemberNovember), and hurricane season (JuneNovember) means of the Niño 3.4 region SST anomalies and the SOI were utilized. Two 


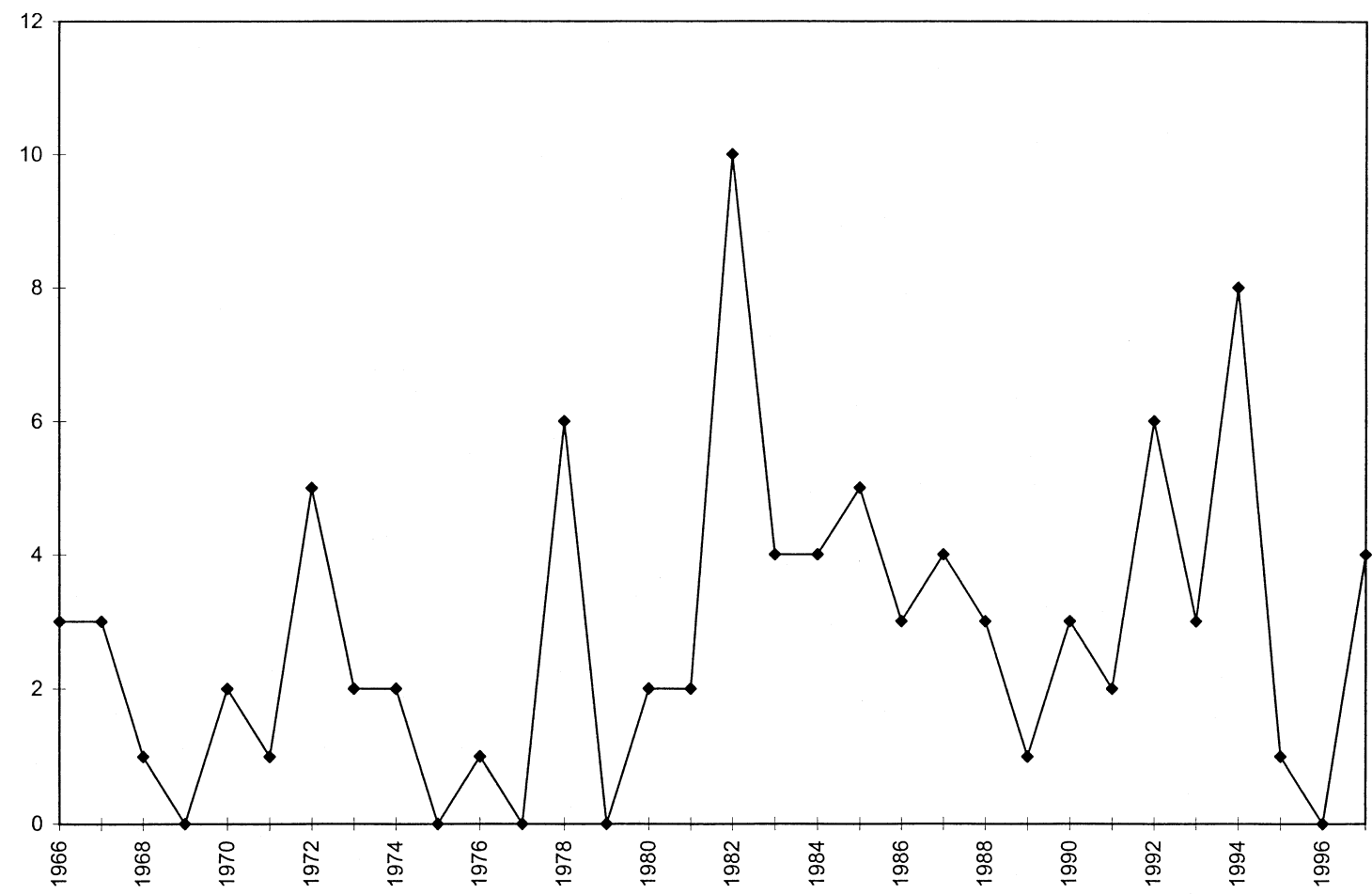

Fig. 2. Time series of annual tropical cyclone counts in the CNP for the years 1966-1997.

Table 1. Pearson correlation coefficients between tropical cyclone counts in the Central North Pacific and time averages of the Nino 3.4 SST and the SOI. *, **, *** denote $90 \%, 95 \%$, and 99\% significance levels, respectively based on a Student's $t$-test taking climatological persistence into account. Summer, fall, and hurricane season means are June-August, September-November, and JuneNovember averages, respectively. TS $+\mathrm{HU}$ and HU denote the number of tropical storms and hurricanes, and the number of hurricanes, respectively.

\begin{tabular}{|c|c|c|c|c|c|c|}
\hline & \multicolumn{3}{|c|}{ Nino 3.4 SST } & \multicolumn{3}{c|}{ SOI } \\
\hline & Summer & Fall & Hurricane & Summer & Fall & Hurricane \\
\hline TS + HU & $0.3428^{\star}$ & $0.332^{\star}$ & $0.3431^{*}$ & $-0.5353^{\star \star \star}$ & $-0.4703^{\star \star \star}$ & $-0.5246^{\star \star \star}$ \\
\hline & & & & & & \\
\hline HU & 0.0752 & 0.1392 & 0.1148 & $-0.3618^{\star \star}$ & $-0.3398^{\star \star}$ & $-0.3668^{\star \star}$ \\
\hline
\end{tabular}

counts of TCs were correlated with the above time averages: the total number of tropical storms and hurricanes ( $\mathrm{TS}+\mathrm{HU}$ ), and the number of hurricanes (HU).

Pearson correlation coefficients for the different counts of TCs and the time averages of both the Niño 3.4 region SST anomalies, and the SOI are given in Table 1. Quenouille's (1952) method was used to account for the reduction of effective numbers of degrees of freedom due to persistence. The effective numbers of degrees of freedom due to persistence $\left(N_{\text {eff }}\right)$ are estimated using the approximation

$$
N_{\mathrm{eff}}=\frac{N}{1+\sum_{i=1}^{5} 2 \gamma_{i x} \gamma_{i y}},
$$

where $N$ is the original sample size of TC and SST series, and $\gamma_{i x}$ and $\gamma_{i y}$ are the autocorrela- 


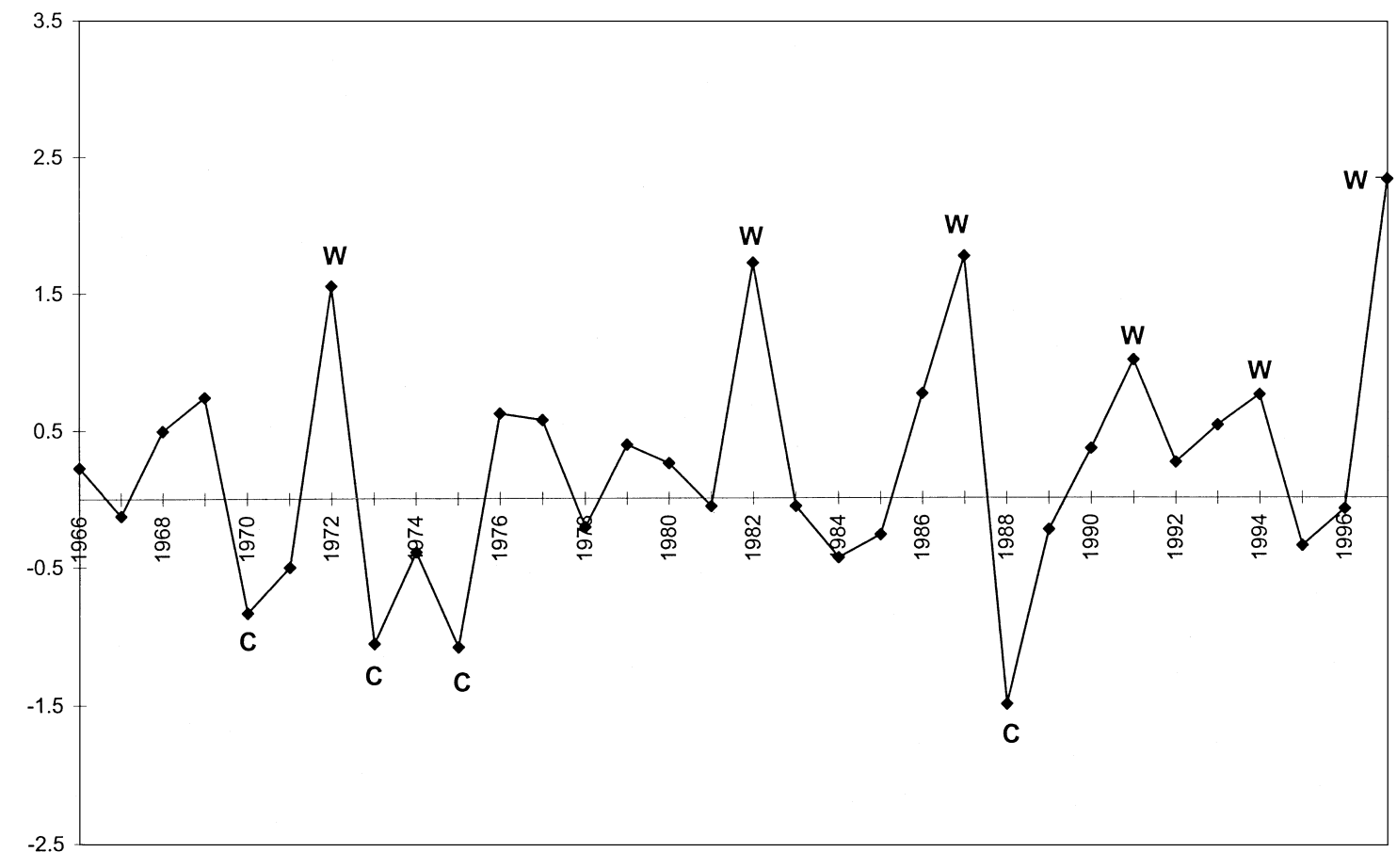

Fig. 3. Time series of hurricane season (June-November) average Niño 3.4 SST anomalies for the years 1966-1997. W's and C's indicate El Niño and La Niña batches, respectively. Anomalies are in units of ${ }^{\circ} \mathrm{C}$.

tion coefficients of TC $(x)$ and SST $(y)$ series at lag $i$, respectively. Because interannual correlations of TC exhibit rapid decay toward zero as the lag $i$ increases, only the first five lags are considered. After temporal degrees of freedom are adjusted, the correlations are evaluated for various significance levels. The correlation coefficients between all TC counts, and Niño 3.4 SST anomalies, are consistently positive, while those between TC counts and the SOI are consistently negative. Also note that the correlation coefficients between the SOI and TC counts are larger than their corresponding values between the SST and TC series. The most pronounced correlation is found between the TS + HU and SOI $(-0.5353)$, where this correlation is significant at the $99 \%$ level based on a Student's $t$ distribution, when climatological persistence is taken into account. This indicates that El Niño years tend to have more TCs, and the significance of the correlation coefficients points out the existence of a general and concurrent relationship between TC counts in the CNP and ENSO.

\subsection{Differences in tropical cyclones between El Niño and La Niña years}

Hurricane season (June-November) means of the Niño 3.4 region SST anomalies were calculated and utilized to define the El Niño and La Niña Hurricane Season (hereafter referred to as ENHS and LNHS, respectively), for the period 1966-1997. Figure 3 is a time series of the hurricane season mean SST anomalies. Those years with a departure of at least $0.75^{\circ} \mathrm{C}$ are designated ENHSs, while the years with an anomaly less than or equal to $-0.75^{\circ} \mathrm{C}$, are defined as LNHSs. A $0.75^{\circ} \mathrm{C}$ threshold was chosen so only strong warm and cold episodes would be included in the analysis. According to this criterion, the hurricane seasons in 1972, 1982, 1987, 1991, 1994, 1997 and 1970, 1973, 1975, 1988 are defined as ENHSs and LNHSs, respectively (Table 2). Note that the summer and 
Table 2. Number of tropical cyclones and June-November averaged SST anomaly for El Nino (left) and La Nina (right) batches. Bold-faced numbers are the respective mean numbers of tropical cyclones.

\begin{tabular}{|c|c|c|}
\hline Year & SST(C) & TC \\
\hline 1997 & 2.33 & 4 \\
\hline 1987 & 1.77 & 4 \\
\hline 1982 & 1.72 & 10 \\
\hline 1972 & 1.55 & 5 \\
\hline 1991 & 1.01 & 2 \\
\hline 1994 & 0.75 & 8 \\
\hline & & $\mathbf{5 . 5}$ \\
\hline
\end{tabular}

\begin{tabular}{|c|c|c|}
\hline Year & SST(C) & TC \\
\hline 1988 & -1.5 & 3 \\
\hline 1975 & -1.09 & 0 \\
\hline 1973 & -1.06 & 2 \\
\hline 1970 & -0.84 & 2 \\
\hline & & 1.75 \\
\hline
\end{tabular}

autumn seasons chosen in the aforementioned years preceded the peak phase of the warm or cold ENSO cycles, which usually occur in boreal winter.

Ten TCs occurred in 1982 and eight in 1994. The annual totals of TCs in the years 1982 and 1994 represent the two highest totals in the past 32 years. The average number of TCs in the ENHS (5.5) triples that in the LNHS (1.75). However, not all the ENHSs have more TC occurrences than the LNHSs, and 1991 is such an example. There were $33 \mathrm{TC}$ occurrences in the CNP in six ENHSs. Out of these 33 TCs, 14 of them (42\%) formed in the CNP, and 19 of them (58\%) propagated into the basin from the east. In contrast, only seven TCs occurred in four LNHSs (Table 2), and three of them (43\%) originated in the CNP. Thus, the CNP serves as a unique hub for which the TC incidence is not only modulated by storms from the eastern Pacific, but also by changes in the dynamic circulation within the CNP.

Figure 4 contrasts the TC tracks during El Niño and La Niña composites. As expected, there is a greater number of TCs which form in the CNP as well as an increased number of TCs which move into the basin from the east during El Niño composites. For both composites, most TCs are concentrated between $10^{\circ} \mathrm{N}$ and $20^{\circ} \mathrm{N}$. There is also not a large difference in the northsouth migration of TC tracks in the CNP between El Niño and La Niña composites. Now that a difference is evident in the numbers and tracks of TCs in the CNP between two extreme climatic events, dynamic circulation parameters which may account for these differences will be discussed.

\section{Variability of dynamic parameters}

\subsection{The eastward extension of the monsoon trough}

Streamline analyses, based on monthly mean $1000 \mathrm{hPa}$ wind data, were utilized to identify the mean location and farthest eastward extent of the monsoon trough during the 32 year period. The $1000 \mathrm{hPa}$ wind data from the 1972 , 1982, 1987, 1991, 1994, and 1997 seasons, and the $1970,1973,1975$, and 1988 seasons were averaged to construct El Niño and La Niña autumn composites, respectively. Figure 5 shows a striking difference in the autumn mean lowlevel circulation between these two extreme composites. During the El Niño autumn composite, stronger southerly flow across the equator extends farther eastward in the Western North Pacific (Fig. 5a). Upon crossing the equator, this southerly flow curves into westerlies, partially due to the Coriolis effect. In the autumn mean composites, the monsoon trough, defined as the shear zone where the trade easterlies meet the equatorial westerlies, extends over 40 degrees farther eastward in the El Niño autumn composite than in the La Niña autumn case (Fig. 5). Tropical disturbances are often found in the trough where there is a weak cyclonic rotation. As the cyclonic vorticity in the trough increases, these systems tend to intensify into tropical storms or hurricanes.

Note that the monsoon trough is not identifiable in Fig. 5b, and the large-scale wind field is basically featureless (i.e., zonal) in the La Niña autumn composite. In addition, the trade-wind trough axis extends more westward in the La Niña autumn than the El Niño autumn, as 


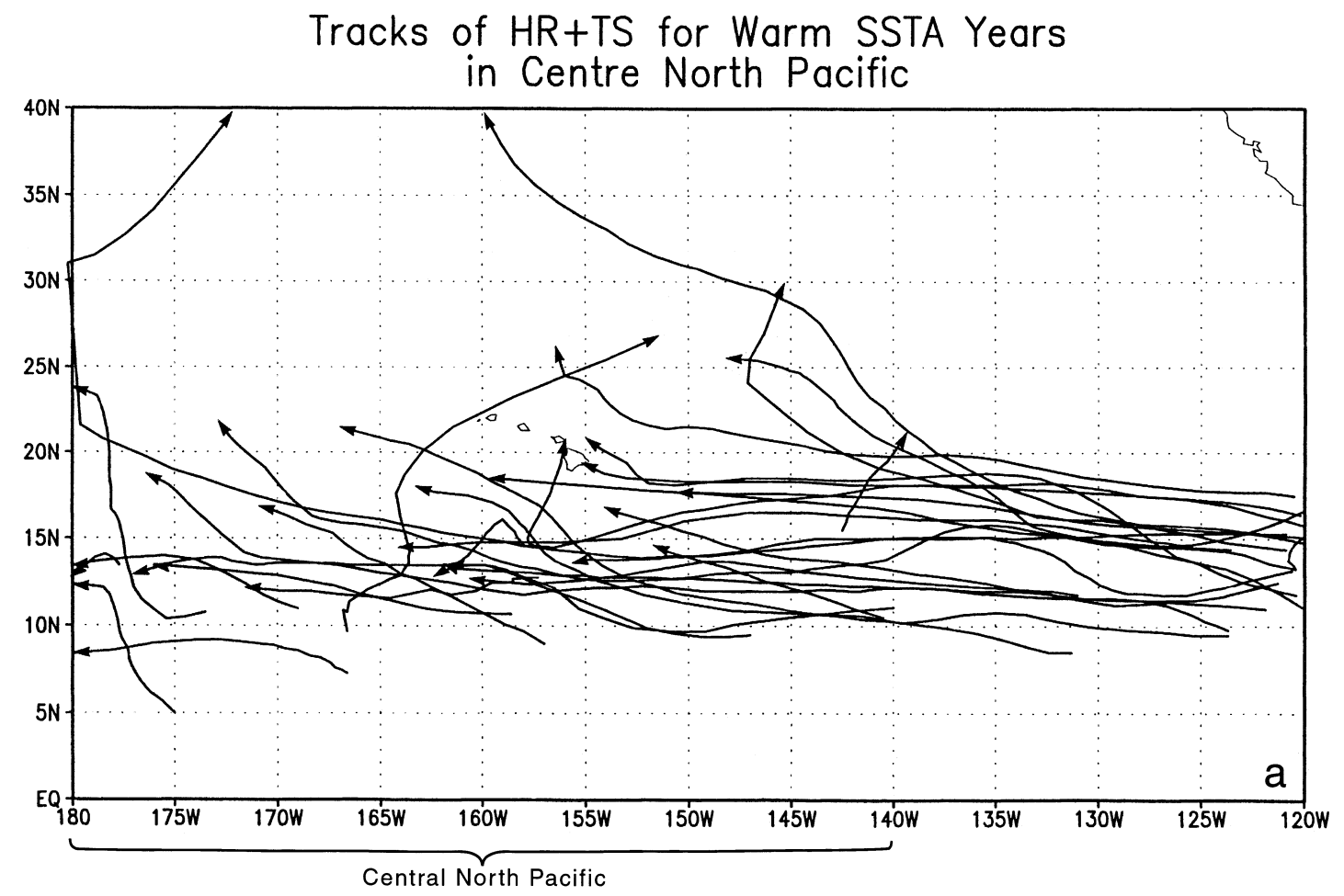

\section{Tracks of HR+TS for Cold SSTA Years \\ in Centre North Pacific}

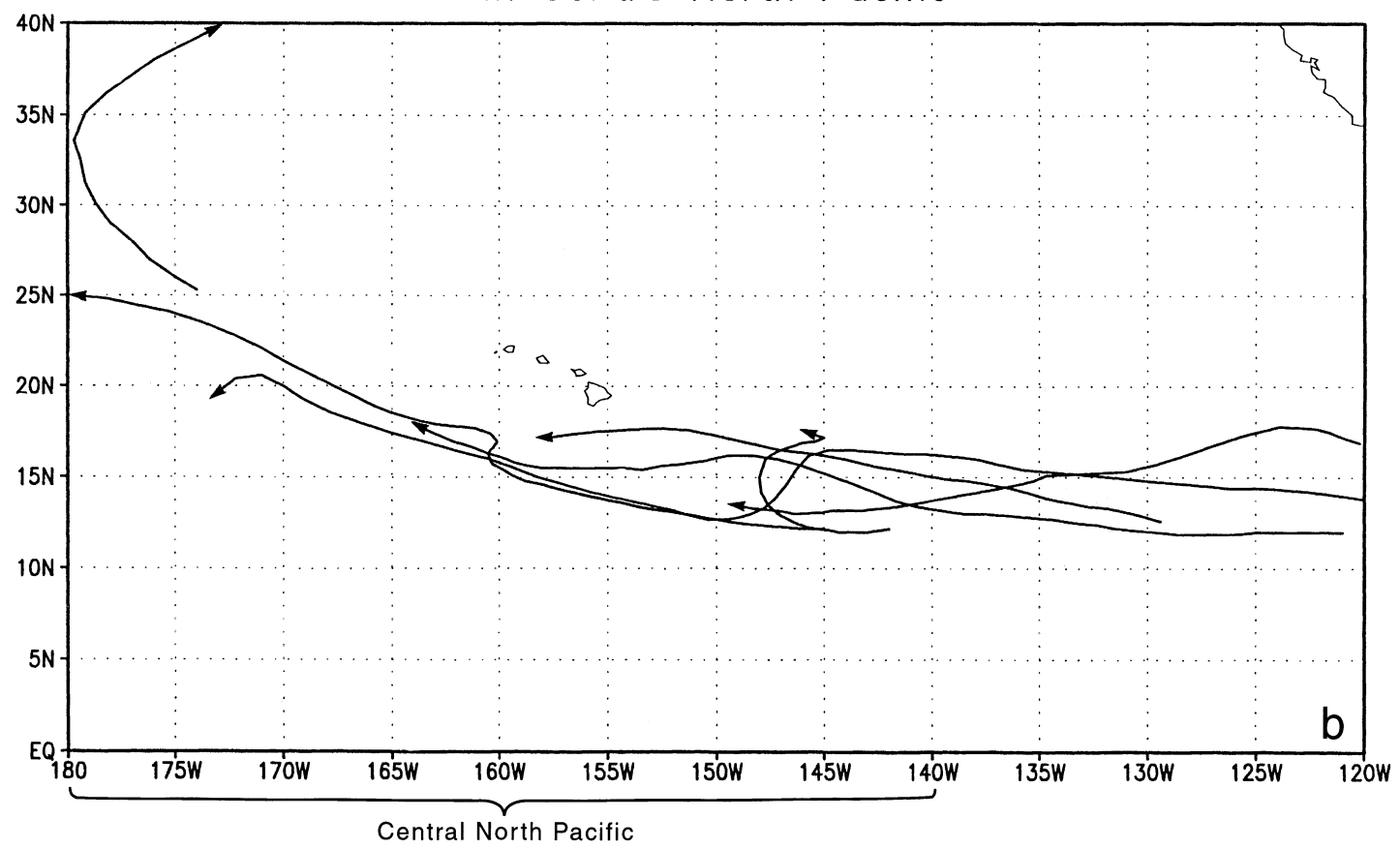

Fig. 4. Tracks of tropical cyclones for (a) El Niño years and (b) La Niña years. Tracks are drawn for tropical cyclones whose maximum sustained surface wind speeds are at least $17.5 \mathrm{~m} \mathrm{~s}^{-1}$. 

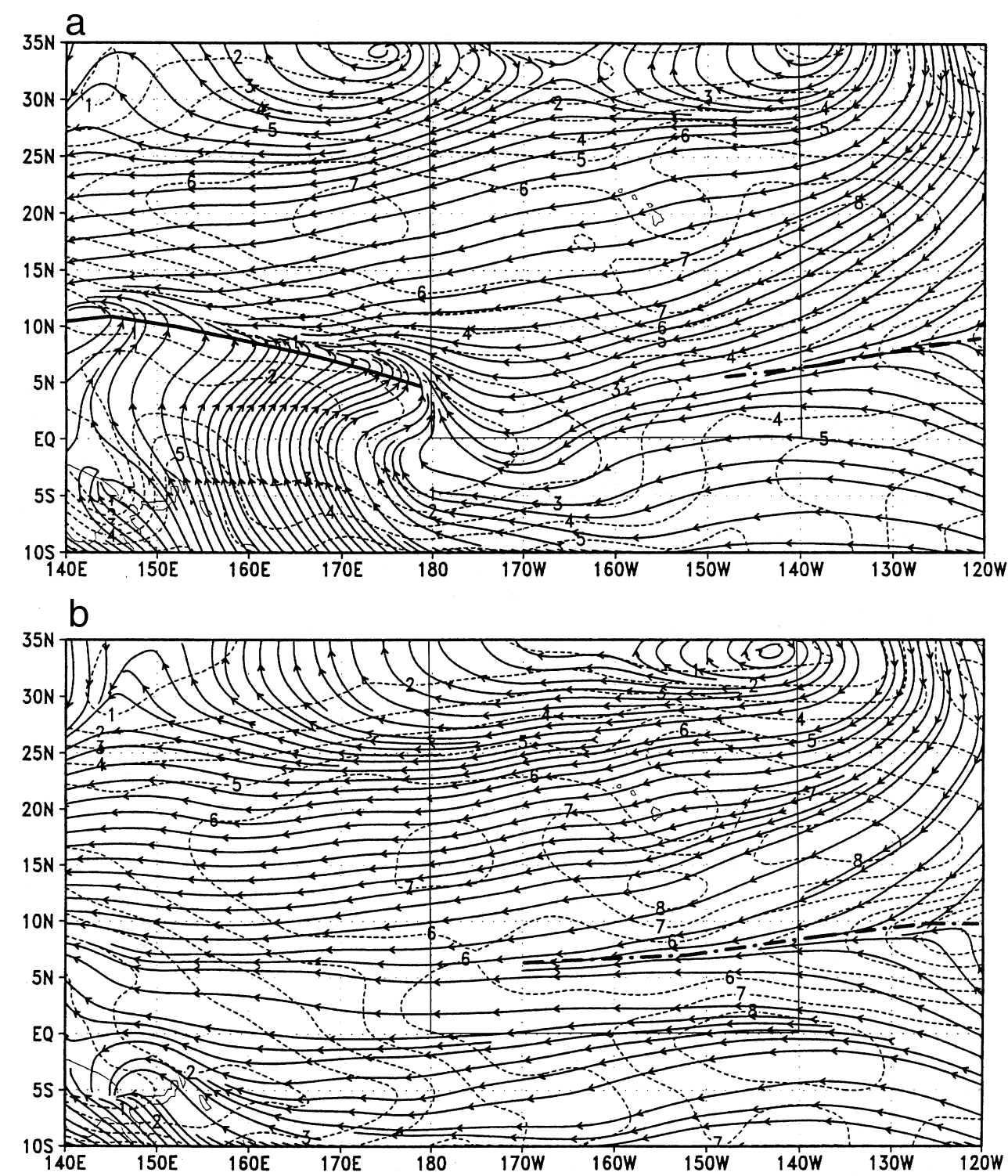

Fig. 5. $1000 \mathrm{hPa}$ streamline analyses for (a) El Niño autumn (September-November) mean composite and (b) La Niña autumn mean composite. Broken lines are contours of wind speed in $\mathrm{m} \mathrm{s}^{-1}$. Heavy solid line in (a) denotes the axis of the monsoon trough. Heavy broken line denotes the axis of the trade-wind trough. The CNP is bordered by thin solid lines.

shown in Fig. 5. Compared to the La Niña autumn case, at $135^{\circ} \mathrm{W}$, the trade-wind trough axis also shifts slightly equatorward in the El Niño autumn composite. For both extremes, the trade winds exhibit a belt of strong wind speed $\left(\geq 7 \mathrm{~m} \mathrm{~s}^{-1}\right)$ near $17^{\circ} \mathrm{N}$, equatorward of the subtropical high. Wind speed is relatively weak along both the monsoon, and trade-wind troughs.
To illustrate the interannual variability of the displacement of the monsoon trough, Fig. 6 shows the easternmost location of the trough in summer and autumn for each individual year. The monsoon trough normally is displaced farther eastward in autumn than in summer (Fig. 6). In the years 1972, 1982, 1994, and 1997, the autumn mean location of the monsoon trough extends into the CNP basin. The years listed 
a

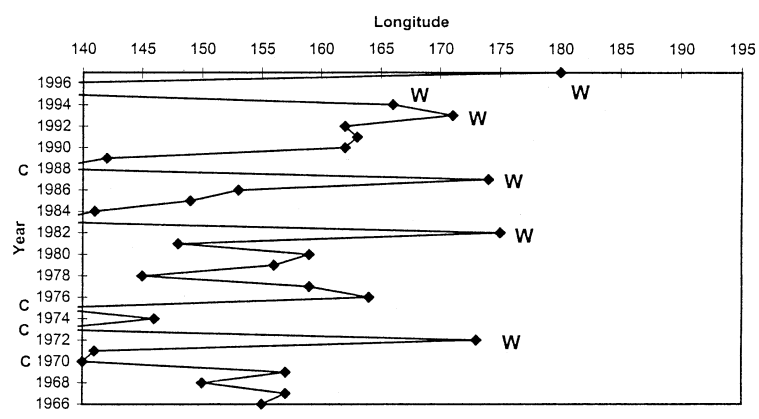

b

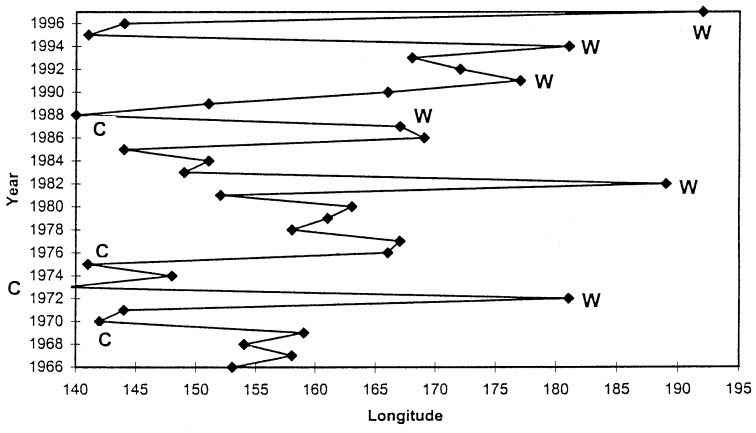

Fig. 6. Time series of the farthest eastward extent of the monsoon trough for the years 1966-1997 for (a) summer (June-August) and (b) autumn means. W's (C's) denote the El Niño summer or autumn composite (La Niña summer or autumn).

above are all categorized as ENHS (Table 2). Lander (1994), and Chen et al. (1998), also found that during low SOI years, the monsoonal westerly winds penetrate farther to the east than during most other years. The genesis location for TCs in the Western North Pacific shifts eastward. On the monthly mean time scale, the displacement of the monsoon trough is more dramatic, sometimes extended well eastward past the composite seasonal mean location. For instance, the trough in November 1982 extends as far east as $155^{\circ} \mathrm{W}$ to the south of Hawaii (Sadler, personal communication). This is a $25^{\circ}$ longitudinal shift $(>2750 \mathrm{~km})$ eastward from the autumn mean location in the El Niño composite (Fig. 5a). The interannual time series of the farthest eastward extent of the monsoon trough (Fig. 6) indicates that during the El Niño summer or autumn, equatorial westerlies accompanied by the monsoon trough extend farther eastward.

\subsection{Low-level relative vorticity}

Figure 7 displays the time series of the July through September mean $1000 \mathrm{hPa}$ relative vorticity averaged over the region from $10^{\circ} \mathrm{N}$ to $20^{\circ} \mathrm{N}$, and from the dateline to $140^{\circ} \mathrm{W}$. July, August and September are the three most active months in the hurricane season. A spatial average of this domain was chosen because it is the area with the most TC activity in the CNP. The El Niño seasonal mean, designated by W, has a larger (more cyclonic) low level relative vorticity value than the La Niña seasonal mean in general.

Figure 8 shows the influence of the monsoon trough on the $1000 \mathrm{hPa}$ relative vorticity field. In the summer mean field, the $3 \times 10^{-6} \mathrm{~s}^{-1}$ contour extends nearly across the area from $160^{\circ} \mathrm{E}$ to $165^{\circ} \mathrm{W}$ in the El Niño summer composite, but is confined in the western Pacific in the La Niña summer composite. For the autumn average, as demonstrated in Fig. 9, the band of cyclonic (positive) relative vorticity in the El Niño autumn composite is two to three times greater in the region from $160^{\circ} \mathrm{E}$ to $150^{\circ} \mathrm{W}$ to the south of Hawaii, when compared to the La Niña autumn composite. This increase in cyclonic vorticity is mainly attributed to the eastward extension of the monsoon trough during El Niño composites (Fig. 6). Likely, it is this increase in the dynamical spinup that accounts mainly for more TCs formed in the CNP. Zehr (1992) also noted that the variation of the low-level vorticity associated with the monsoon trough in the northwestern Pacific plays a dominant role in TC activity on the seasonal time scale.

In the region from $150^{\circ} \mathrm{W}$ to $130^{\circ} \mathrm{W}$, the mean El Niño and La Niña autumn composite vorticity fields, are comparable in magnitude with a contour value of $3 \times 10^{-6} \mathrm{~s}^{-1}$ (Fig. 9). The band of cyclonic relative vorticity in this area is broader, and extends farther equatorward, in the El Niño autumn when compared to the La Niña autumn. For example, at $140^{\circ} \mathrm{W}$ the band of cyclonic relative vorticity extends from $5^{\circ} \mathrm{N}$ to $17^{\circ} \mathrm{N}$ in the El Niño autumn composite, while in the La Niña autumn, the area extends from roughly $8^{\circ} \mathrm{N}$ to $16^{\circ} \mathrm{N}$. Thus, the 


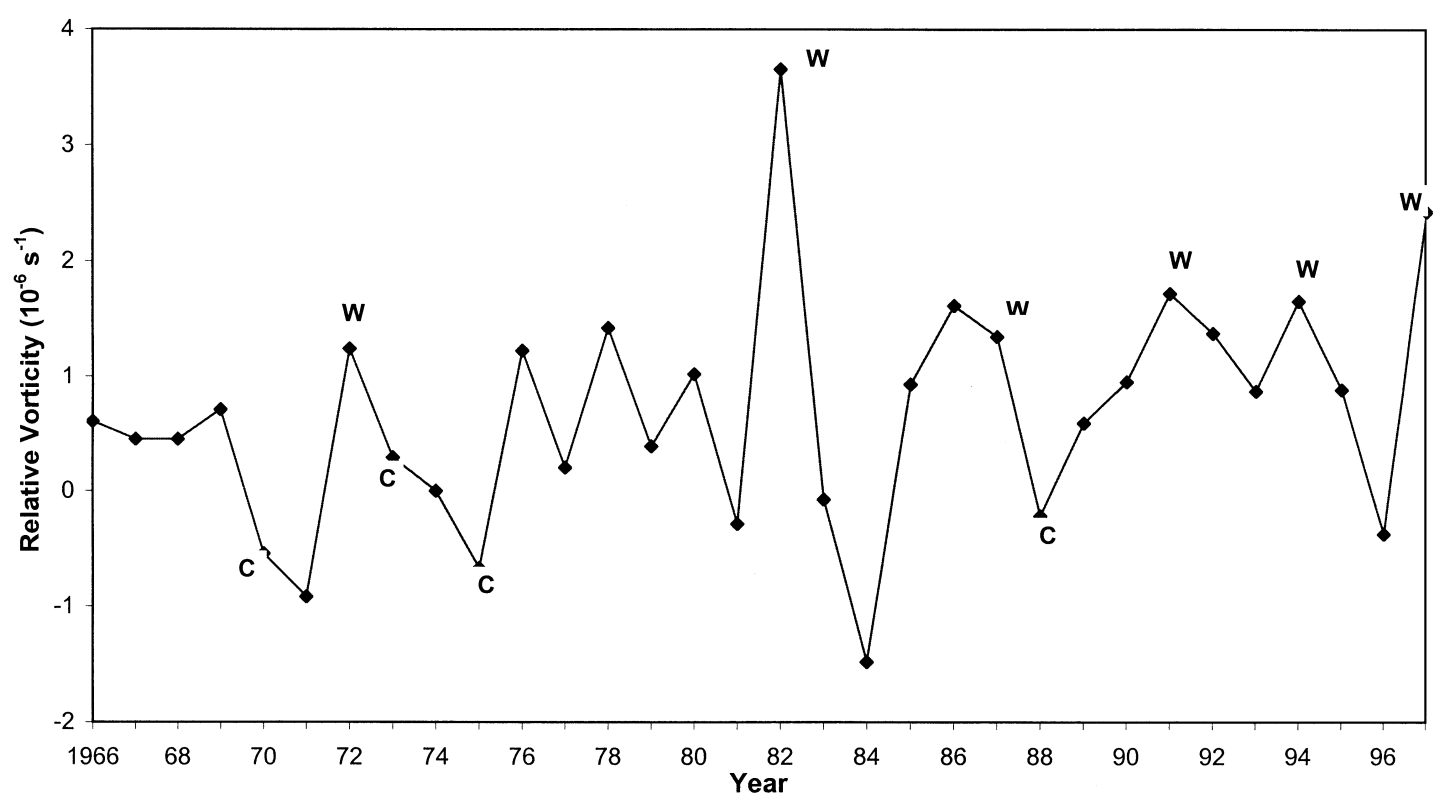

Fig. 7. Time series of July-September mean $1000 \mathrm{hPa}$ relative vorticity averaged over $\left(10^{\circ} \mathrm{N}-20^{\circ} \mathrm{N}\right.$, $180^{\circ}-140^{\circ} \mathrm{W}$ ) for the years 1966-1997. W's (C's) denote the El Niño (La Niña) seasonal mean composite. Units are $10^{-6} \mathrm{~s}^{-1}$.

$3 \times 10^{-6} \mathrm{~s}^{-1}$ contour line spans a latitudinal band 12 degrees wide in the El Niño autumn, in contrast to an eight-degree band in the La Niña autumn. The three-degree expansion in the El Niño autumn composite may be due to the southward shift in the location of the tradewind trough, a feature also noted by Rasmusson and Carpenter (1982). Farther to the east, away from the $\mathrm{CNP}\left(130^{\circ} \mathrm{W}-120^{\circ} \mathrm{W}\right)$ centered near $12^{\circ} \mathrm{N}$, vorticity values are actually greater in the La Niña autumn than in the El Niño autumn.

A peculiar feature in the $1000 \mathrm{hPa}$ relative vorticity fields, in both Figs. 8 and 9, is the local maximum which occurs upstream of the Hawaiian Islands. This maximum is due to the orographic blocking effect by the island of Hawai'i. By chance, a grid point in the data set is near this island. The blocking effect reduces the wind speed dramatically at this lone grid point with the flow to the north, and south of this point much greater. This produces a dipole feature with a positive local maximum to the north of $18^{\circ} \mathrm{N}$, and a negative local maximum (not displayed) to the south of this point. According to Sadler et al. (1987), the surface wind velocity decreases upwind of the Hawaiian Islands. However, this observed decrease in the surface winds does not produce an observed vorticity dipole as great as that shown in Figs. 8 and 9. The grid space of the vorticity data, and the fact that a grid point lies on the island of Hawai'i, create an artificial increase in the magnitude and spatial scale of the dipole feature near the island chain. This spurious feature is not an observed characteristic near the Hawaiian Islands at the spatial scale displayed in Figs. 8 and 9.

\subsection{Tropospheric vertical wind shear}

Tropospheric vertical wind shear (VWS) is defined as the magnitude of the difference between the zonal and meridional wind at $200 \mathrm{hPa}$ and $850 \mathrm{hPa}$ and is given by the equation

$$
\begin{aligned}
\mathrm{VWS}= & {\left[\left(u_{200 \mathrm{hPa}}-u_{850 \mathrm{hPa}}\right)^{2}\right.} \\
& \left.+\left(v_{200 \mathrm{hPa}}-v_{850 \mathrm{hPa}}\right)^{2}\right]^{1 / 2} .
\end{aligned}
$$

Figure 10 displays the summer and autumn means of the VWS when the La Niña seasonal composite is subtracted from the El 
a

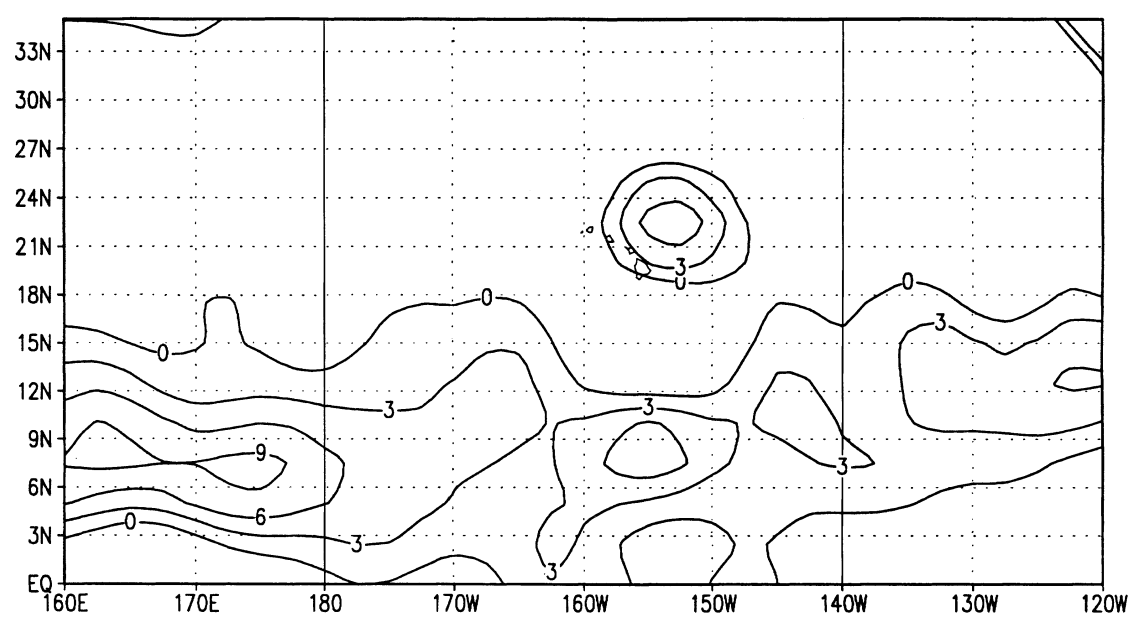

b

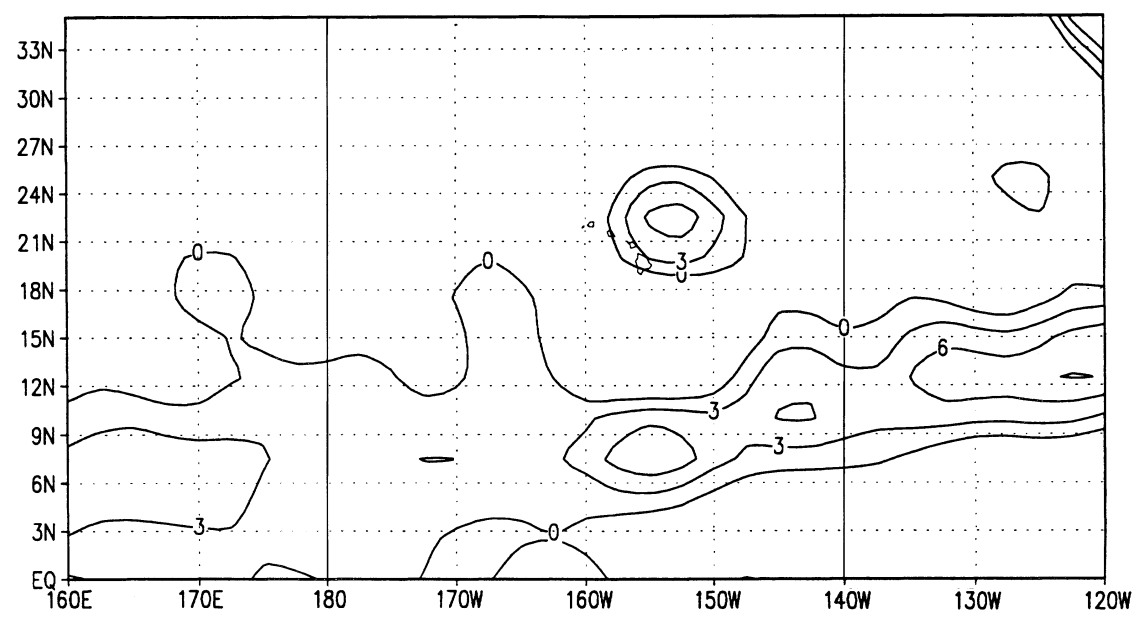

Fig. 8. $1000 \mathrm{hPa}$ relative vorticity for (a) El Niño summer mean composite and (b) La Niña summer mean composite. Units are $10^{-6} \mathrm{~s}^{-1}$ and the contour interval is 3 . Only positive values are contoured. The domain of the CNP is delineated by thin solid lines.

Niño seasonal composite. Negative (positive) values denote that the vertical shear is weaker (stronger) in the El Niño seasonal composite. In the region from the equator to about $15^{\circ} \mathrm{N}$, where most TCs in the CNP occur, the difference in VWS is especially apparent between the two contrasting composites. In this area, values range from 0 to $-16 \mathrm{~m} \mathrm{~s}^{-1}$ in summer, and from 0 to $-28 \mathrm{~m} \mathrm{~s}^{-1}$ in autumn. When a TC moves into an area of strong tropospheric VWS, the low-level center loses its upper level outflow channel, and usually dissipates quickly (Gray 1968). Strong VWS also disrupts the organization of deep convection around the low-level circulation center, which inhibits intensification of the incipient disturbance. Because VWS is smaller in El Niño seasonal composites, TCs entering the CNP from the eastern North Pacific would encounter less shear and, therefore, be able to maintain their intensity in such years. 
a

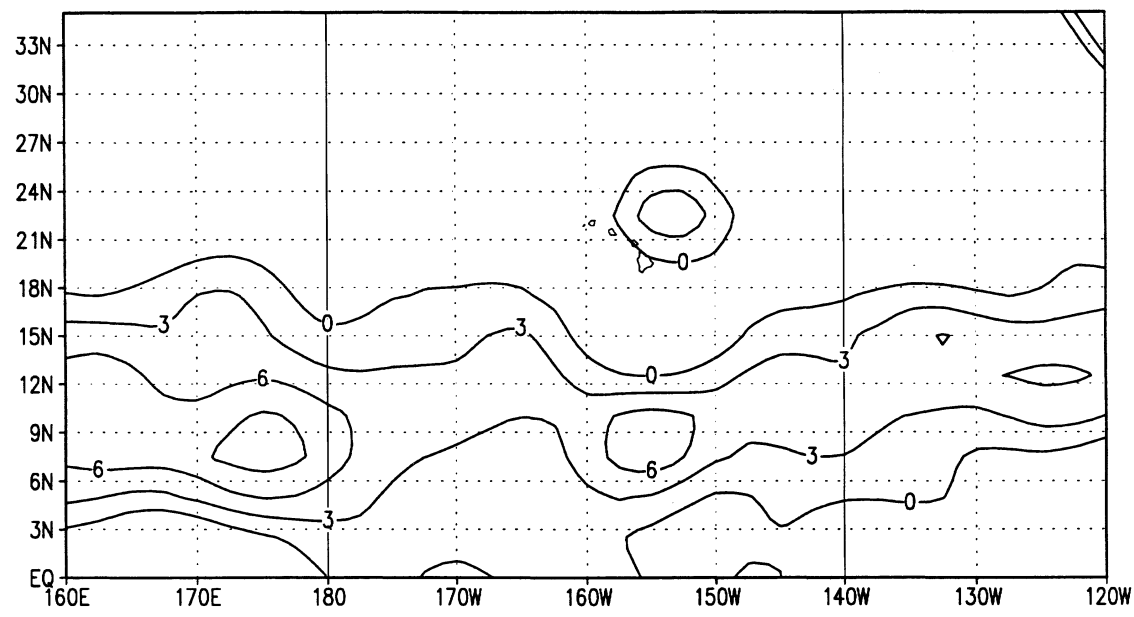

b

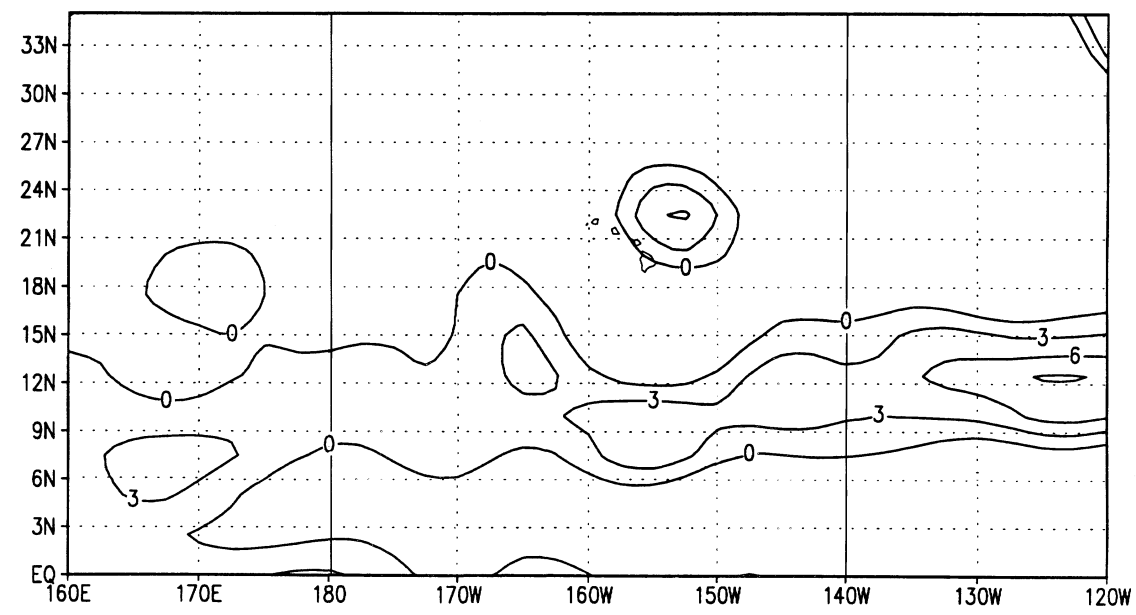

Fig. 9. Same as in Fig 8 except for autumn mean.

\subsection{Dynamic potential term in Gray's seasonal genesis parameter}

Gray's (1977) seasonal genesis parameter (SGP) can be divided into a dynamic potential, and a thermal potential. The thermal potential consists of the ocean energy parameter, the moist stability parameter, and the humidity parameter, while the dynamic potential (DP) includes the vorticity parameter, the Coriolis parameter, and the vertical shear parameter. The DP term is given by the following equation:

$$
\mathrm{DP}=(f)\left(\zeta_{r}+5\right)[1 /(\mathrm{VWS}+3)],
$$

where $f$ is the Coriolis parameter (units of $\mathrm{s}^{-1}$ ), $\zeta_{r}$ is $1000 \mathrm{hPa}$ relative vorticity $\left(10^{-6} \mathrm{~s}^{-1}\right)$, and VWS is given in equation (2), and in units of $\mathrm{m} \mathrm{s}^{-1}$.

Gray (1977) found that the moist stability parameter was sufficient for TC genesis in the Pacific except for subtropical regions in winter. The ocean energy parameter inhibits genesis poleward of roughly $30^{\circ} \mathrm{N}$ in the North Pacific in summer and fall, but otherwise is adequate during those seasons. The thermodynamic parameters in the SGP are necessary, but not sufficient, conditions for TC genesis (McBride 
a

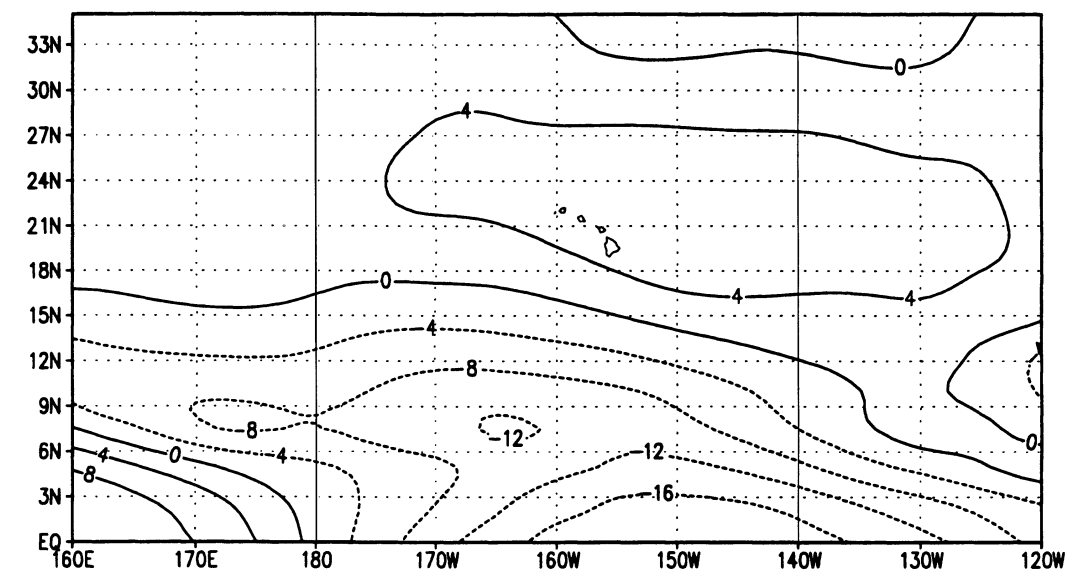

$\mathrm{b}$

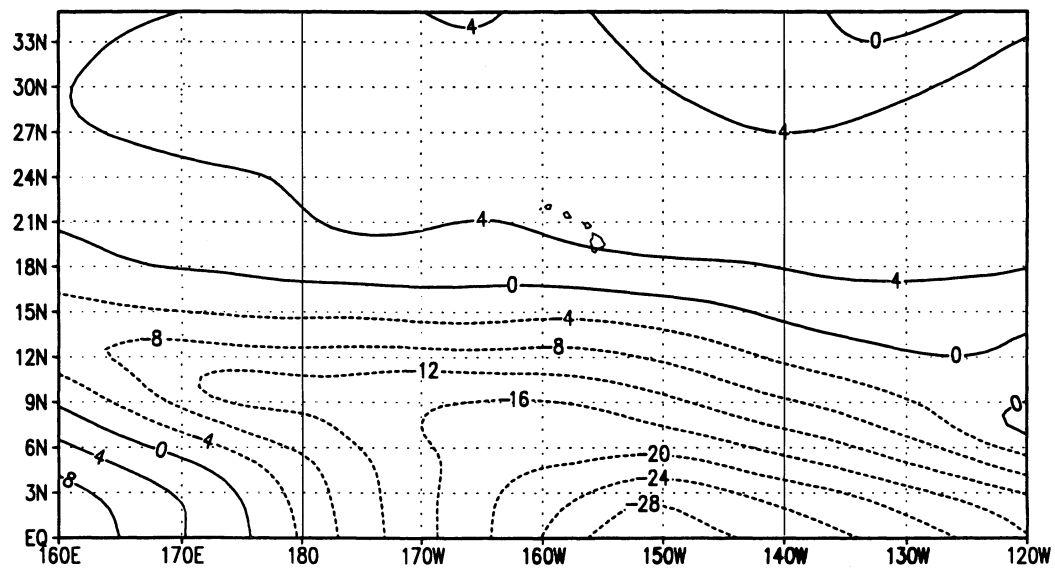

Fig. 10. Difference in tropospheric vertical wind shear when the La Niña summer composite is subtracted from the El Niño summer composite (a) and when the La Niña autumn composite is subtracted from the El Niño autumn composite (b). Units are $\mathrm{m} \mathrm{s}^{-1}$ and the contour interval is 4 . Positive and negative contours are given by solid and dashed lines, respectively. The domain of the CNP is delineated by thin solid lines.

1981). Assuming the thermal conditions are met during the hurricane season in the CNP, analyzing DP attempts to determine the areas in the domain with the most potential for TC genesis. By incorporating the vertical shear parameter, DP also attempts to quantify the ability for a TC to maintain its intensity.

Under the above assumptions, the fluctuation of DP would influence the number of TCs in the CNP. Because more TCs occur in ENHSs than in LNHSs (Table 2), greater values of DP are expected in the ENHS composite than that in the LNHS composite. Watterson et al. (1995) found a significant correlation in the CNP between a GCM simulated SGP, and the observed number of TCs.

Figure 11 contrasts July-September average DP composites. In almost the entire CNP $\left(180^{\circ}-145^{\circ} \mathrm{W}\right)$ in the latitude band from $6^{\circ} \mathrm{N}$ to $15^{\circ} \mathrm{N}$, DP values are two to three times greater in the El Niño seasonal composite than in the La Niña composite. In the El Niño seasonal composite, maximum DP values are greater than $4\left([650 \mathrm{hPa}]^{-1} \times 10^{-11} \mathrm{~m}^{-1} \mathrm{~s}^{-1}\right)$, 


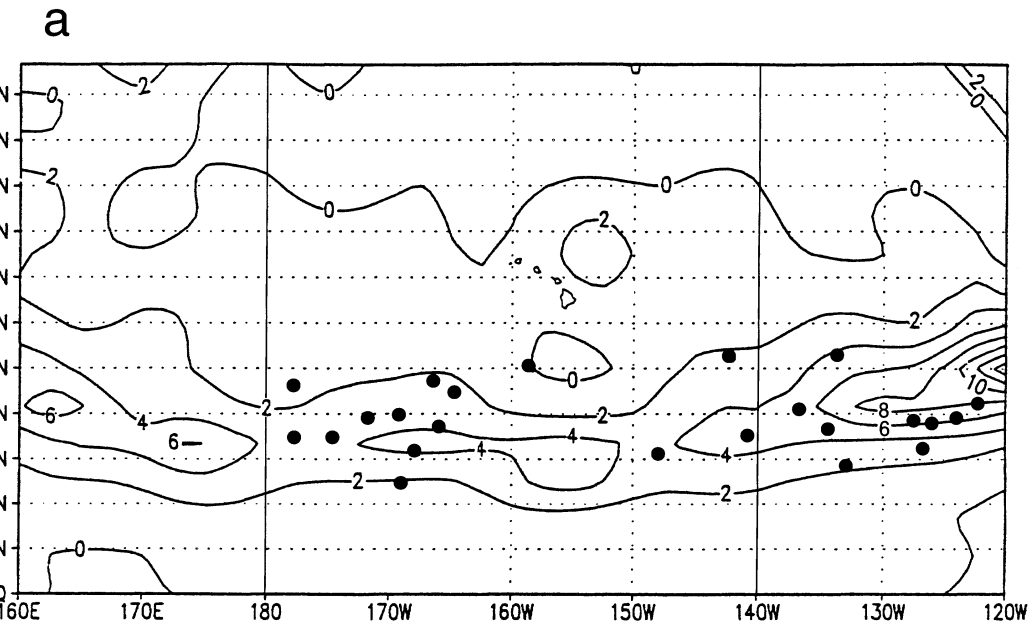

b

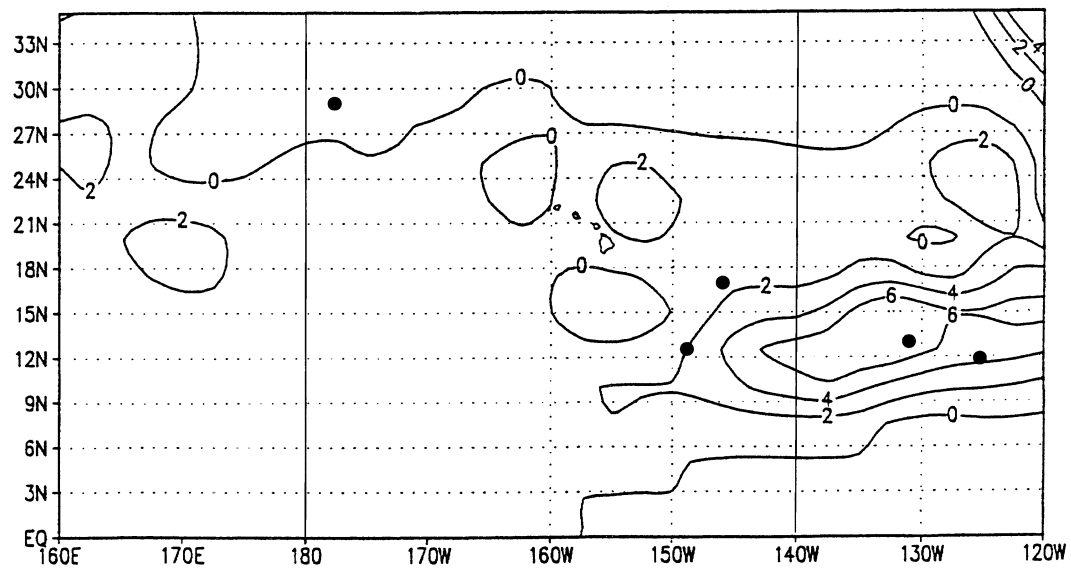

Fig. 11. July-September dynamic potential for (a) El Niño seasonal mean and (b) La Niña seasonal mean composites. Units are $(650 \mathrm{hPa})^{-1} \times 10^{-11} \mathrm{~m}^{-1} \mathrm{~s}^{-1}$ and the contour interval is 2 . Dots denote initial detection points of named storms which either formed in the CNP or moved to the CNP from east. Those storms which originated outside the easternmost boundary $\left(120^{\circ} \mathrm{W}\right)$ are not included. The CNP is delineated by thin solid lines.

while in the La Niña seasonal composite, DP values are about 2 or less than 2 $\left([650 \mathrm{hPa}]^{-1} \times 10^{-11} \mathrm{~m}^{-1} \mathrm{~s}^{-1}\right)$ over the same domain. Moreover, in the El Niño seasonal composite, DP values are greater in the region from $130^{\circ} \mathrm{W}$ to $120^{\circ} \mathrm{W}$. The combined effect of the increased low-level cyclonic vorticity and the reduced VWS, as reflected in the DP, corresponds well with the increased TC frequency during the El Niño seasonal composite. Figure 11 also shows the initial detection points of all TCs when they reached at least tropical storm strength. Because some TCs formed to the east of the study domain (i.e., to the east of $120^{\circ} \mathrm{W}$ ), the total number of named storms shown here is less than that in Table 2. Most detection points lie within the band where DP values are relatively high $\left(>2[650 \mathrm{hPa}]^{-1} \times 10^{-11} \mathrm{~m}^{-1} \mathrm{~s}^{-1}\right)$, for both composites.

\section{Summary and discussion}

Investigations of the interannual variability of the eastward extension of the monsoon trough, the low level relative vorticity fields, 
the tropospheric vertical wind shear, and the dynamic potential term in Gray's (1977) SGP revealed a strong relationship between these dynamic parameters on the seasonal time scale, and the interannual variability of TCs in the CNP. The results of this research are summarized below.

First, the effect of ENSO on TC frequency in the CNP was quantified by calculating Pearson correlation coefficients between the CNP TC counts, and both the Niño 3.4 SST anomalies and the SOI. Correlation coefficients between TC counts and SOI were significant to at least the $95 \%$ level. TC seasons tend to be more active when there are large, positive SST anomalies in the Niño 3.4 region or large, negative SOI values.

Six El Niño, and four La Niña hurricane seasons (ENHSs and LNHSs, respectively), were identified according to the Niño 3.4 hurricane season average SST anomalies to examine the differences in the numbers and tracks of TCs. The average number of TCs in ENHS is triple that in LNHS. In terms of cyclones originating in the CNP, fourteen TCs were found during six ENHSs but only three during four LNHSs. Moreover, 19 TCs propagated into the basin from the east during six ENHSs, in contrast to only four during four LNHSs. Thus, a simple average indicates that 3.2 TCs moved eastward into the CNP in warm ENSO years in contrast to only $1 \mathrm{TC}$ in cold years. Likewise, on average, 2.3 TCs formed in the CNP in warm years, versus 0.75 in cold years.

Three variables related to $\mathrm{TC}$ genesis and maintenance were considered to account for the differences in TC tracks and numbers in the CNP between two extreme composites. The variability of the eastward extension of the monsoon trough, the low level relative vorticity fields, and the vertical wind shear (VWS) all play a role in the interannual variability of TCs in the CNP. In the ENHS composite, when the monsoon trough extends farther eastward and often into the CNP, the presence of equatorial westerlies, and the increased low level cyclonic vorticity, creates a local environment more favorable for TC genesis in this region. An El Niño summer or autumn composite of VWS shows a two to three times reduction equatorward of $16^{\circ} \mathrm{N}-17^{\circ} \mathrm{N}$ when compared to the corresponding La Niña composite. The median TC days that were calculated for ENHS and LNHS were close to the same for systems entering the CNP. However, the genesis locations of TC in the Eastern North Pacific shifted westward in El Niño years (Irwin and Davis 1999; Kimberlain 1999). Accordingly, TCs would tend to propagate further west, and perhaps enter into the CNP during ENHS simply because they formed further west. This, together with the fact that vertical wind shear is less in an El Niño seasonal composite, would explain why TCs that form in the Eastern Pacific during ENHSs are more likely to propagate into the CNP.

Applying the DP term from Gray's (1977) SGP to the CNP summarizes the integrated effects of low level relative vorticity, and VWS on $\mathrm{TC}$ genesis and frequency on the seasonal time scale. Most initial detection points of named storms are confined within a band of relatively high DP values. Therefore, the DP could be used as a diagnostic tool to determine where TC genesis is mostly likely to occur. The increased TC occurrences during ENHSs in the CNP are also reflected in the increased values of the DP in the El Niño composite. Overall, these increased values are conducive to (a) more TCs formed in the CNP, and (2) a tendency for TC originated in the Eastern Pacific to enter the CNP.

\section{Acknowledgments}

Funding for this study was provided by the NWS Pacific Fellowship to the Department of Meteorology at the University of HawaiiManoa through NOAA Cooperative Agreement. Partial support was provided by the First Insurance Company of Hawaii and the Guy/ Carpenter Reinsurance Company. Thanks are due to Thomas Schroeder for beneficial discussions. Two anonymous reviewers and Dr. Y.N. Takayabu provided helpful comments which clarified the presentation of this paper. We also thank Maria Rokotondrafara for computer programming assistance, and Di Henderson for technical editing. This is the SOEST contribution number 5972.

\section{References}

Barnston, A.G., M. Chelliah, and S.B. Goldenberg, 1997: Documentation of a highly ENSOrelated SST region in the equatorial Pacific. Atmosphere-Ocean, 35, 367-383. 
Basher, R.E. and X. Zheng, 1995: Tropical cyclones in the southwest Pacific: Spatial patterns and relationships to Southern Oscillation and sea surface temperature. J. Climate, 8, 1249-1260.

Chan, J.C.L., 1985: Tropical cyclone activity in the northwest Pacific in relation to the El Niño/ Southern Oscillation phenomenon. Mon. Wea. Rev., 113, 599-606.

- 2000: Tropical cyclone activity over the western North Pacific associated with El Niño and La Niña events. J. Climate, 13, 29602972.

Chen, T.-C., S.-P. Weng, N. Yamazaki, and S. Kiehne, 1998: Interannual variation in the tropical cyclone formation over the western north Pacific. Mon. Wea. Rev., 126, 1080-1090.

Chu, P.-S., 2002: Large-scale circulation features associated with decadal variations of tropical cyclone activity over the Central North Pacific. J. Climate, in press.

Chu, P.-S. and J. Wang, 1997: Tropical cyclone occurrences in the vicinity of Hawaii: Are the differences between El Niño and non-El Niño years significant?. J. Climate, 10, 2683-2689.

Chu, P.-S. and J. Wang, 1998: Modeling return periods of tropical cyclone intensities in the vicinity of Hawaii. J. Appl. Meteor., 37, 951-960.

Chu, P.-S. and J.D. Clark, 1999: Decadal variations of tropical cyclone activity over the central North Pacific. Bull. Amer. Meteor. Soc., 80, 1875-1881.

Gray, W.M., 1968: Global view of the origin of tropical disturbances and storms. Mon. Wea. Rev., 96, 669-700.

, 1977: Tropical cyclone genesis in the western North Pacific. J. Meteorol. Soc., Japan, 55, 465-482.

, 1984: Atlantic seasonal hurricane frequency. Part I: El Niño and $30 \mathrm{mb}$ quasi-biennial oscillation influences. Mon. Wea. Rev., 112, 16491668.

, 1990: Strong association between West African rainfall and U.S. landfall of intense hurricanes. Science, 249, 1251-1256.

Irwin, R.P. and R.E. Davis, 1999: The relationship between the Southern Oscillation Index and tropical cyclone tracks in the eastern North Pacific. Geophys. Res. Lett., 20, 2251-2254.

Kalnay, E. and coauthers, 1996: The NCEP/NCAR 40-year reanalysis project. Bull. Amer. Meteor. Soc., 77, 437-471.

Kimberlain, T.B., 1999: The effects of ENSO on North Pacific and North Atlantic tropical cyclone activity. Proceedings of the $23^{\text {rd }}$ Conference on Hurricanes and Tropical Meteorology, Dallas, TX, Amer. Meteor. Soc., Boston, 250253.
Lander, M.A., 1994: An exploratory analysis of the relationship between tropical storm formation in the western North Pacific and ENSO. Mon. Wea. Rev., 122, 636-651.

Landsea, C.W. and W.M. Gray, 1992: The strong association between western Sahelian monsoon rainfall and intense Atlantic hurricanes. $J$. Climate, 5, 435-453.

Landsea, C.W., W.M. Gray, P.W. Mielke Jr., and K.J. Berry, 1992: Long-term variations of Western Sahelian monsoon rainfall and intense U.S. landfalling hurricanes. J. Climate, 5, 15281534.

Mayfield, M. and E.N. Rappaport, 1992: Eastern North Pacific hurricane season of 1991. Mon. Wea. Rev., 120, 2697-2708.

McBride, J.L., 1981: Observational analysis of tropical cyclone formation. Part I: Basic description of data sets. J. Atmos. Sci., 38, 11171131.

Quenouille, M.A., 1952: Associated measurements, Butterworths, London, $242 \mathrm{pp}$.

Rasmusson, E.M. and T.H. Carpenter, 1982: Variations in tropical sea surface temperatures and surface wind fields associated with the Southern Oscillation/El Niño. Mon. Wea. Rev., 110, 354-384.

Sadler, J.C., 1967: The tropical upper tropospheric trough as a secondary source of typhoons and a primary source of tradewind disturbances. HIG-67-12, University of Hawaii, Honolulu, 44 pp.

1983: Tropical Pacific atmospheric anomalies during 1982-83. Papers from 1982/83 El Niño/ Southern Oscillation Workshop, Miami, FL, 34 November, NOAA/AOML, 1-10.

, M.A. Lander, A.M. Hori, and L.K. Oda, 1987: Tropical Marine Climatic Atlas, Volume II, Pacific Ocean. UHMET 87-02, Department of Meteorology, University of Hawai'i, Honolulu, $27 \mathrm{pp}$.

Shapiro, L.J., 1987: Month-to-month variability of the Atlantic tropical circulation and its relationship to tropical storm formation. Mon. Wea. Rev., 115, 2598-2614.

Shapiro, L.J. and S.B. Goldenberg, 1998: Atlantic sea surface temperatures and tropical cyclone formation. J. Climate, 11, 578-590.

Trenberth, K.E., 1997: The definition of El Niño. Bull. Amer. Meteor. Soc., 78, 2771-2777.

Watterson, I.G., J.L. Evans, and B.F. Ryan, 1995: Seasonal and interannual variability of tropical cyclogenesis: diagnostics from large-scale fields. J. Climate, 8, 3052-3066.

Zehr, R.M., 1992: Tropical cyclogenesis in the western North Pacific. NOAA Tech. Rep., NESDIS 61, U.S. Dept. of Commerce, 181 pp. 